\title{
THE SYNERGY BETWEEN THE PERCEPTION OF THE IMPORTANCE OF KNOWLEDGE AND GOAL SETTING IN POLISH MANUFACTURING COMPANIES
}

\author{
Marcin Soniewicki, Poznan University of Economics and Business, marcin.soniewicki@ue.poznan.pl
}

\begin{abstract}
The importance of goal setting in companies has already been recognised by many authors. Nevertheless, in the current knowledge-based economy, planning is very difficult, especially for manufacturing companies. This is because in such conditions services are more profitable and manufacturing companies experience a lot of competition from Asia. This is especially important in Poland where this branch of industry still accounts for 25\% of GDP. As a result, manufacturing companies need to become more innovative and concentrate on knowledge. Therefore, this article is an attempt to test the following hypothesis: goal setting is much more effective in terms of a manufacturing company's competitiveness when the enterprise perceives knowledge development as the most significant element of its strategy. The article is based on results of a quantitative empirical study involving 334 Polish manufacturing companies. The data were analysed using SPSS and SAS software. The results clearly show that best results are achieved when both elements - awareness of the importance of knowledge and goal settingare present to a high degree. Nevertheless, knowledge seems to be slightly more important for low and mediumlow technology manufacturing firms. In contrast, in high and medium-high technology manufacturing enterprises more emphasis is placed on goal setting.
\end{abstract}

Keywords: knowledge, goal setting, manufacturing companies, competitiveness.

\section{INTRODUCTION}

For many authors dealing with the topic of organizational performance goal setting is a crucial issue (White and Flores, 1987; Locke and Latham, 2002; Xenikou and Simosi, 2006; Healthcare Registration, 2010). One of the most important articles in this field is one written by Locke and Latham (2002), in which they summarize 25 years of research on goal setting. They underline that goal setting indeed increases performance, as has been demonstrated by many researches. The authors point out that goals can increase performance not only of units and groups, but also of organizations (Locke and Latham, 2002). This is what some sort of organizations do - for example, banks are known to pay much attention to setting very precise goals (Kaźmierczyk, 2011, p. 16, 17). Why are goals so important for success? Woldt (2015) underlines that it is because they are motivating. One crucial element for success is a vision, which is properly divided into clear goals (Healthcare Registration, 2010). This means that companies should plan their strategies, visions and divide them into specific, smaller, measurable, short and long term goals, which are known to the company's employees. Wheelen, Hunger, Hoffman and Bamford claim that companies should plan their strategy in four steps - environmental scanning, defining long term objectives and short term goals, defining strategy implementation and finally control and evaluation (Roth, 2015, p. 6). Roth $(2015$, p. 6) underlines that the second phase - defining long and short term goals - strongly depends on the previous stage - environmental scanning. So the task of setting objectives as well as goals depends on the company's knowledge, which needs to be constantly accumulated. Roth $(2015$, p. 6$)$ also emphasises that the pace of change keeps increasing, so proper planning is becoming more and more difficult. This difficulty is associated with features of our contemporary, global economy.

Nowadays economy is commonly called knowledge-based economy. It is related to the economic changes in the global economy that have taken place in the last decades. The primary one is the growing importance of knowledge (Gaczek, 2009, p. 27). However, one of the foremost characteristics of knowledge-based economy is its continuous variability and unpredictability. We are witnessing a very fast technological development. New products and competitors are constantly entering the market (Powell and Snellman, 2004, pp. 199-220), which makes long term planning very difficult for companies. For example, IT industry companies earn $70 \%$ of their revenue from products and services which did not exist two years ago (Neef, Siesfeld and Cefola, 1998, p. 7). This is why companies need to constantly develop their knowledge and capabilities in order to survive in the market and remain competitive (Woodall, Lee and Stewart, 2004, p. 165; Soniewicki, 2015, 2016). 


\section{Issues in Information Systems \\ Volume 18, Issue 2, pp. 20-30, 2017}

The other feature of knowledge-based economy is the concentration on services not on physical goods (Neef, Siesfeld and Cefola, 1998, p. 4). Obviously, the demand for physical goods still remains but it is not as high as used to be. The situation in the knowledge-based economy is particularly difficult for manufacturing companies, which operate in a global, highly competitive economy (Stansfield and Longenecker, 2004). They have to face competition from low cost countries, such as China, India or Vietnam.

Taking into account the above considerations, this aim of this article is to verify the following hypothesis: goal setting is much more effective in terms of a manufacturing company's competitiveness when the enterprise perceives knowledge development as the most significant element of its strategy. There are many types of knowledge which companies need in order to be competitive, but this article concentrates on firms' perception of the importance of developing this resource.

This issue is very important around the world as globalization is moving forward. Nevertheless, it is especially important in Poland, because manufacturing is an important element of the Polish economy and it accounts for around 25\% of Poland's GDP (Drozdowicz-Bieć, 2014).

\section{METHODOLOGY}

This article is based on data collected in a survey conducted in 2011 and the beginning of 2012. The sample was selected from the Kompass Poland database. Two kinds of questionnaires were used: an online questionnaire and a traditional paper-based questionnaire sent by mail. Over 1200 companies took part in the survey, of which 334 were manufacturing firms. These companies were divided into two groups using the method developed by OECD (Hatzichronoglou, 1997) - Table 1.

Table 1. The structure of the sample

\begin{tabular}{|r|c|c|}
\hline $\begin{array}{c}\text { Technological } \\
\text { level of } \\
\text { manufactured products }\end{array}$ & $\begin{array}{c}\text { Share of } \\
\text { companies in the } \\
\text { sample }\end{array}$ & $\begin{array}{c}\text { No. of companies } \\
\text { in the sample }\end{array}$ \\
\hline Low and medium-low technology & $53.9 \%$ & 180 \\
\hline High and medium-high technology & $46.1 \%$ & 154 \\
\hline Total: & $100.0 \%$ & 334 \\
\hline
\end{tabular}

The study was designed to investigate knowledge management processes and market orientation intensity, but this article concentrates on two questions included in the questionnaire. The first one tested the perception of the importance of knowledge by the surveyed companies: "From the perspective of our company's strategy, constant knowledge development is the most important element of competing". The second one was designed to check whether surveyed companies establish specific goals and communicate them to their employees: "Our company has specific goals and plans for upcoming years recorded in writing and known to employees". Respondents in the survey were asked to assess how these findings correspond to the situation in their company on the following 5point Likert scale: 1 - I do not agree completely, 2 - I do not agree, 3 - it is difficult to say (neutral response), 4 I agree, 5 - I completely agree. In the analysis the value of 4 was selected as the cut-off point because only answers "I agree" (4) and "I completely agree" (5) can be considered as positive.

The company's level of competitiveness was measured using a modified version of Competitiveness Index developed by Fonfara (2007). In this version of the index, respondents were asked to assess their company's position against their closest competitors in three fields: profit, value of sales and market share. There were five options to choose from: 1 - much worse, 2 - worse, 3 - more less the same, 4 - better, 5 - much better. The final value of the modified Competitiveness Index for each company was an arithmetic average of the three dimensions. For purposes of the analysis, two statistics were used: the Mann-Whitney U test implemented in IBM SPSS software. The second was logistic regression performed with SAS software. The particular p-values were marked according to the following scheme: $* * *$ p-value $<0.01, * *$ p-value $<0.05, *$ p-value $<0.1$. 


\section{Issues in Information Systems}

Volume 18, Issue 2, pp. 20-30, 2017

\section{RESEARCH RESULTS}

The first analysis concentrates on the influence of the perception of the importance of knowledge on competitiveness of various manufacturing companies.

Table 2. Importance of knowledge perception and competitiveness of manufacturing companies

\begin{tabular}{|c|c|c|c|c|}
\hline Company type & importance of knowledge & Competitiveness Index & $\begin{array}{c}\text { share in the } \\
\text { sample }\end{array}$ & $\begin{array}{c}\text { No. of } \\
\text { companies }\end{array}$ \\
\hline \multirow{3}{*}{$\begin{array}{l}\text { All manufacturing } \\
\text { companies }\end{array}$} & $<4$ & 2.83 & $41.6 \%$ & 139 \\
\hline & $\geq 4$ & 3.34 & $58.4 \%$ & 195 \\
\hline & Difference: & $0.50 * * *$ & \multicolumn{2}{|c|}{ p-value $<0.001$} \\
\hline \multirow{3}{*}{$\begin{array}{l}\text { Low and medium- } \\
\text { low technology } \\
\text { manufacturing } \\
\text { companies }\end{array}$} & $<4$ & 2.82 & $47.2 \%$ & 85 \\
\hline & $\geq 4$ & 3.36 & $52.8 \%$ & 95 \\
\hline & Difference: & $0.54 * * *$ & \multicolumn{2}{|c|}{$p$-value $<0.001$} \\
\hline \multirow{3}{*}{$\begin{array}{l}\text { High and medium- } \\
\text { high technology } \\
\text { manufacturing } \\
\text { companies }\end{array}$} & $<4$ & 2.86 & $35.1 \%$ & 54 \\
\hline & $\geq 4$ & 3.32 & $64.9 \%$ & 100 \\
\hline & Difference: & $0.45 * * *$ & \multicolumn{2}{|c|}{$p$-value $=0.004$} \\
\hline
\end{tabular}

As can be seen in Table 2, a majority of manufacturing companies - almost 60\% - view knowledge as important. Nonetheless, over $40 \%$ of manufacturing companies do not value knowledge equally highly. The difference in competitiveness between these two groups is quite large -0.50 . Moreover, one must underline that Competitiveness Index of 2.83 is below the middle value (3.00), which means that such companies are less competitive than their closest competitors. A similar situation can be observed in a more detailed analysis of two groups of manufacturing companies.

In the case of low and medium low technology manufacturing companies the results show that their attitude to knowledge has a slightly bigger effect on their competitiveness than in the entire sample of manufacturing companies (Competitiveness Index difference - 0.54). For high and medium-high technology companies, many more firms perceive knowledge as the most important factor of their strategy $-65 \%$. The difference in competitiveness is also quite large -0.45 and companies that do not appreciate this resource are less competitive than their closest competitors. However, the difference in competitiveness is lower than in the case of low and medium-low technology manufacturing companies.

The following analysis concentrates on the second factor taken into account in this article - goal setting - table 3 .

Table 3. Goal setting and competitiveness of manufacturing companies

\begin{tabular}{|c|c|c|c|c|}
\hline $\begin{array}{c}\text { Type of analyzed } \\
\text { companies }\end{array}$ & Goal setting & Competitiveness Index & $\begin{array}{c}\text { Share in the } \\
\text { sample }\end{array}$ & $\begin{array}{c}\text { No. of } \\
\text { companies }\end{array}$ \\
\hline \multirow{3}{*}{$\begin{array}{c}\text { All manufacturing } \\
\text { companies }\end{array}$} & $<4$ & 2.90 & $58.1 \%$ & 194 \\
\hline & $\geq 4$ & 3.44 & $41.9 \%$ & 140 \\
\hline & Difference: & $0.53 * * *$ & \multicolumn{2}{|c|}{$p$-value $<0.001$} \\
\hline \multirow{3}{*}{$\begin{array}{c}\text { Low and medium-low } \\
\text { technology } \\
\text { manufacturing } \\
\text { companies } \\
\end{array}$} & $<4$ & 2.92 & $58.3 \%$ & 105 \\
\hline & $\geq 4$ & 3.35 & $41.7 \%$ & 75 \\
\hline & Difference: & $0.43 * * *$ & \multicolumn{2}{|c|}{$p$-value $<0.001$} \\
\hline \multirow{3}{*}{$\begin{array}{c}\text { High and medium- } \\
\text { high technology } \\
\text { manufacturing } \\
\text { companies } \\
\end{array}$} & $<4$ & 2.88 & $57.8 \%$ & 89 \\
\hline & $\geq 4$ & 3.54 & $42.2 \%$ & 65 \\
\hline & Difference: & $0.66 * * *$ & \multicolumn{2}{|c|}{$p$-value $<0.001$} \\
\hline
\end{tabular}

The first thing that can be noticed in Table 3 is that far fewer manufacturing companies set goals than perceive knowledge as an important factor of their strategy. In the entire group, including low and medium-low as well as medium-high and high technology companies - it is around $42 \%$. The second finding is that also in the case of goal setting companies that do not attach much importance to this factor are less competitive than their closest competitors (Competitiveness Index > 3.00). It must be underlined that the influence of goal setting on 


\section{Issues in Information Systems}

Volume 18, Issue 2, pp. 20-30, 2017

competitiveness varies. For low and medium-low technology manufacturing companies it is 0.43 ; for high and medium-high technology companies it is 0.66 . In the second case the difference is especially large.

The analyses discussed so far indicate that low and low-technology companies should pay more attention to knowledge, while high and medium-high technology companies should attach more importance to goal setting. Nevertheless, for a better understanding of the issue, a closer inspection of both elements combined is necessary, which will be presented in the next part of the article.

In the following analysis, manufacturing companies' attitude to knowledge and goal setting was compared in order to look for synergy effects between them. Table 4 shows competitiveness of manufacturing companies with various attitudes in the two key areas.

Table 4. Competitiveness of manufacturing companies with various attitudes to the importance of knowledge

\begin{tabular}{|c|c|c|c|c|}
\hline \multirow{2}{*}{$\begin{array}{c}\text { Importance of } \\
\text { knowledge }\end{array}$} & Goal setting & $\begin{array}{c}\text { Competitiveness } \\
\text { Index }\end{array}$ & Share in the sample & No. of companies \\
\hline \multirow{3}{*}{$<4$} & $<4$ & 2.80 & $33.8 \%$ & 113 \\
\cline { 2 - 5 } & $\geq 4$ & 3.00 & $7.8 \%$ & 26 \\
\hline \hline \multirow{2}{*}{$\geq 4$} & Difference: & 0.20 & $p$-value $=0.296$ & - \\
\cline { 2 - 5 } & $<4$ & 3.05 & $24.3 \%$ & 81 \\
\hline \multicolumn{2}{|c|}{ Difference: } & $\mathbf{0 . 4 8 * * *}$ & $\mathbf{p}$-value $<\mathbf{0 . 0 0 1}$ & - \\
\hline \hline \multicolumn{2}{|c|}{ Difference (both $\geq 4$ - both $<4$ ): } & $\mathbf{0 . 7 4 * * *}$ & $\boldsymbol{p}$-value $<\mathbf{0 . 0 0 1}$ & - \\
\hline
\end{tabular}

According to Table 4, when a company's attitude to knowledge is low, goal setting can only increase its competitiveness to an average level (3.00). The second part of the table shows that companies which appreciate the importance of knowledge and do not set goals are slightly more competitive than their closest competitors. In fact, there are relatively many such firms in the sample - over $25 \%$. Nevertheless, companies which consider knowledge particularly valuable and, in addition, have a similarly positive attitude to goal setting are the most competitive.

The next step of the investigation consisted in conducting statistical analysis using logistic regression. The model consisted of two independent variables - goal setting (x1), importance of knowledge (x2) and one dependent variable - Competitiveness Index (y). The model quality diagnostics are presented in Table 5.

Table 5. Testing Global Null Hypothesis

\begin{tabular}{|r|c|c|c|}
\hline \multicolumn{4}{|c|}{ Testing Global Null Hypothesis: BETA=0 } \\
\hline Test & Chi-Square & DF & Pr $>$ ChiSq \\
\hline Likelihood Ratio & 41.2092 & 2 & $<\mathbf{0 . 0 0 0 1}$ \\
\hline Score & 40.2712 & 2 & $<\mathbf{0 . 0 0 0 1}$ \\
\hline Wald & 37.6853 & 2 & $<\mathbf{0 . 0 0 0 1}$ \\
\hline
\end{tabular}

Source: results produced using SAS software

Table 5 shows that the null hypothesis should be rejected and the resulting model is reliable. The following table shows the summary of maximum likelihood estimates.

Table 6. Analysis of Maximum Likelihood Estimates

\begin{tabular}{|c|c|c|c|c|c|}
\hline \multicolumn{6}{|c|}{ Analysis of Maximum Likelihood Estimates } \\
\hline Parameter & $D F$ & Estimate & Standard Error & Wald Chi-Square & $\operatorname{Pr}>C h i S q$ \\
\hline Intercept & 1 & -3.1347 & 0.4860 & 41.5952 & $<0.0001$ \\
\hline Goal setting & 1 & 1.1480 & 0.2535 & 20.5149 & $<0.0001$ \\
\hline $\begin{array}{r}\text { Importance of } \\
\text { knowledge }\end{array}$ & 1 & 0.6385 & 0.2645 & 5.8298 & 0.0158 \\
\hline
\end{tabular}

Source: results produced using SAS software 


\section{Issues in Information Systems}

Volume 18, Issue 2, pp. 20-30, 2017

As can be seen in Table 6, all variables are statistically significant (for $\alpha=0.05$ ). Table 7 shows odds ratio estimates. For manufacturing companies that set goals, in comparison to those that do not, the probability of being more competitive than their closest competitors is almost 3.2 times higher. For companies which perceive knowledge as an important factor, in comparison to those that do not, the probability of being more competitive than their closest competitors is around 1.9 times higher. Table 8 presents values of R-Square and max-rescaled R-Square.

Table 7. Odds Ratio Estimates

\begin{tabular}{|r|c|c|c|}
\hline \multicolumn{4}{|c|}{ Odds Ratio Estimates } \\
\hline Effect & $\begin{array}{c}\text { Point } \\
\text { Estimate }\end{array}$ & \multicolumn{2}{|c|}{$\begin{array}{c}\text { 95\% Wald } \\
\text { Confidence Limits }\end{array}$} \\
\hline Goal setting & 3.152 & 1.918 & 5.180 \\
\hline Importance of knowledge & 1.894 & 1.128 & 3.180 \\
\hline
\end{tabular}

Source: results produced using SAS software

Table 8. R-Square and Max-rescaled R-Square for all manufacturing companies

\begin{tabular}{|l|l|l|l|}
\hline$R$-Square & 0.1161 & Max-rescaled R-Square & 0.1573 \\
\hline
\end{tabular}

Source: results produced using SAS software

The most important R-Square value is relatively low but acceptable for such models. It shows a medium to low goodness-of-fit of the model to the data. The following figure shows the ROC Curve for the model.

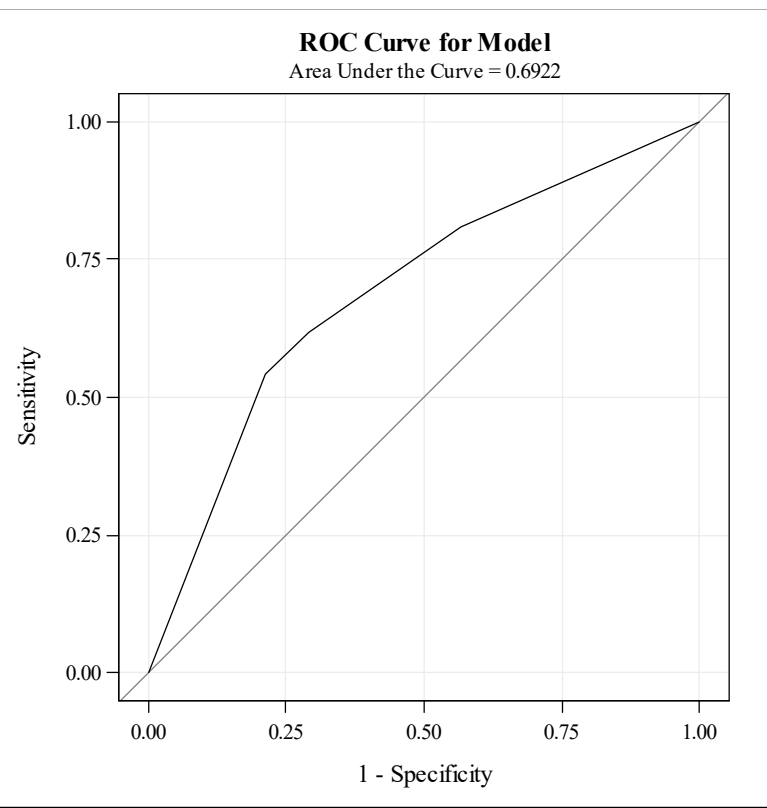

Figure 1. ROC Curve for the model - all manufacturing companies Source: results produced using SAS software

The ROC curve is relatively distant from the centre, which means that the model is valid. The area under the curve is also significant -0.6922 .

In the next step the two groups of manufacturing companies (low and medium-low vs. medium-high and high technology) will be analysed separately. The following table contains results for low and medium-low technology manufacturing companies. 


\section{Issues in Information Systems}

Volume 18, Issue 2, pp. 20-30, 2017

Table 9. The competitiveness of low and medium-low manufacturing companies with various attitudes to the importance of knowledge and goal setting

\begin{tabular}{|c|c|c|c|c|}
\hline $\begin{array}{l}\text { Importance of } \\
\text { knowledge }\end{array}$ & Goals setting & $\begin{array}{c}\text { Competitiveness } \\
\text { Index }\end{array}$ & Share in the sample & No. of companies \\
\hline \multirow{2}{*}{$<4$} & $<4$ & 2.81 & $39.4 \%$ & 71 \\
\hline & $\geq 4$ & 3.00 & $7.8 \%$ & 14 \\
\hline \multicolumn{2}{|r|}{ Difference: } & 0.19 & $\mathrm{p}$-value $=0.752$ & - \\
\hline \multirow{2}{*}{$\geq 4$} & $<4$ & 3.17 & $18.9 \%$ & 34 \\
\hline & $\geq 4$ & 3.46 & $33.9 \%$ & 61 \\
\hline \multicolumn{2}{|c|}{ Difference: } & $0.30 * *$ & $p$-value $=0.035$ & - \\
\hline \multicolumn{2}{|c|}{ Difference (both $\geq 4$ - both $<4$ ): } & $0.66 * * *$ & $p$-value $<0.001$ & - \\
\hline
\end{tabular}

According to Table 9, differences between these enterprises are smaller than in the entire sample but synergy is still visible. It is particularly worth noting that there is still a large difference between companies that show positive attitudes in the two key areas and those that do not. Moreover, as was previously, it seems that for low and mediumlow technology companies the appreciation of knowledge is the most important. Without it, as the first three rows of Table 9 show, goal setting does not influence competitiveness of these firms. Nevertheless, one must remember that paying attention to both key areas is a lot more beneficial not only to these companies but to the other manufacturing enterprises.

The next step involved testing the logistic regression model for low and medium-low technology manufacturing companies, analogically as in the case of all manufacturing firms combined. Table 10 presents the model quality diagnostics.

Table 10. Testing Global Null Hypothesis

\begin{tabular}{|r|c|c|c|}
\hline \multicolumn{4}{|c|}{ Testing Global Null Hypothesis: BETA $=\mathbf{0}$} \\
\hline Test & Chi-Square & DF & Pr $>$ ChiSq \\
\hline Likelihood Ratio & 20.4300 & 2 & $<\mathbf{0 . 0 0 0 1}$ \\
\hline Score & 19.9099 & 2 & $<\mathbf{0 . 0 0 0 1}$ \\
\hline Wald & 18.6524 & 2 & $<\mathbf{0 . 0 0 0 1}$ \\
\hline
\end{tabular}

Source: results produced using SAS software

As was the case with all manufacturing firms combined, the null hypothesis should be rejected and the model is valid when only low and medium-low technology manufacturing companies are taken into account. The next table presents the corresponding maximum likelihood estimates.

Table 11. Analysis of Maximum Likelihood Estimates

\begin{tabular}{|r|c|c|c|c|c|}
\hline \multicolumn{7}{|c|}{ Analysis of Maximum Likelihood Estimates } \\
\hline Parameter & DF & Estimate & $\begin{array}{c}\text { Standard } \\
\text { Error }\end{array}$ & $\begin{array}{c}\text { Wald } \\
\text { Chi-Square }\end{array}$ & Pr $>$ ChiSq \\
\hline Intercept & 1 & -3.0979 & 0.6334 & 23.9190 & $<\mathbf{0 . 0 0 0 1}$ \\
\hline Goal setting & 1 & 0.7896 & 0.3603 & 4.8014 & $\mathbf{0 . 0 2 8 4}$ \\
\hline Importance of knowledge & 1 & 0.9102 & 0.3697 & 6.0616 & $\mathbf{0 . 0 1 3 8}$ \\
\hline
\end{tabular}

Source: results produced using SAS software

Table 11 shows that all the variables are statistically significant for $\alpha=0.05$. Nevertheless, the value for goal setting is lower than in the case of all manufacturing firms.

Table 12 shows odds ratio estimates. 
Table 12. Odds Ratio Estimates

\begin{tabular}{|r|c|c|c|}
\hline \multicolumn{4}{|c|}{ Odds Ratio Estimates } \\
\hline Effect & $\begin{array}{c}\text { Point } \\
\text { Estimate }\end{array}$ & \multicolumn{3}{|c|}{$\begin{array}{c}\text { 95\% Wald } \\
\text { Confidence Limits }\end{array}$} \\
\hline Goal setting & 2.202 & 1.087 & 4.463 \\
\hline Importance of knowledge & 2.485 & 1.204 & 5.129 \\
\hline
\end{tabular}

Source: results produced using SAS software

The results presented in Table 12 show that for low and medium-low manufacturing companies which set goals, in comparison to such entities that do not, the probability of being more competitive than their closest competitors is 2.2 times higher. For firms which perceive knowledge as an important factor, in comparison to those that do not, the probability of being more competitive than their closest competitors is around 2.5 times higher.

Table 13 contains R-Square and max-rescaled R-Square values.

Table 13. R-Square and Max-rescaled R-Square

\begin{tabular}{|r|r|r|r|}
\hline$R$-Square & 0.1073 & Max-rescaled $R$-Square & 0.1464 \\
\hline
\end{tabular}

As can be seen, R-Square value is 0.1073 , which is very low. This means a low goodness-of-fit for low and medium-low technology manufacturing companies. Figure 2 shows the ROC Curve for the model.

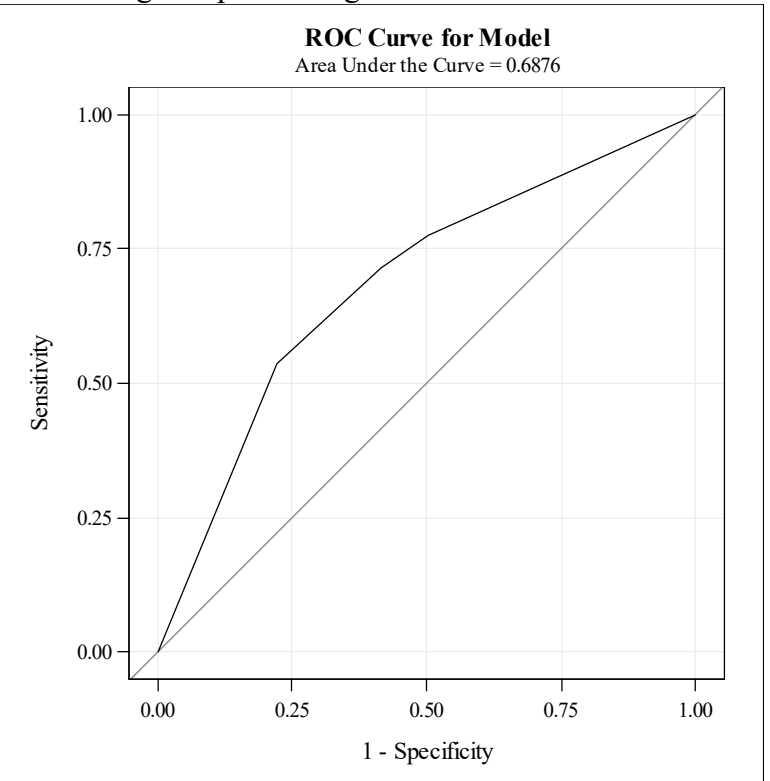

Figure 2. ROC Curve for the model - low and medium low technology manufacturing companies Source: results produced using SAS software

ROC curve is quite distant from the centre but less than in the case of all manufacturing companies combined. Still, the area under the curve is larger than 0.5 .

In the next part of the article we analyse high and medium-high technology manufacturing companies, summarising the findings about the importance of knowledge and goal setting in Table 14. 
Table 14. Competitiveness of high and medium-high technology manufacturing companies with various attitudes to the importance of knowledge and goal setting

\begin{tabular}{|c|c|c|c|c|}
\hline $\begin{array}{c}\text { Importance of } \\
\text { knowledge }\end{array}$ & Goal setting & $\begin{array}{c}\text { Competitiveness } \\
\text { Index }\end{array}$ & Share in the sample & No. of companies \\
\hline \multirow{2}{*}{$<4$} & $<4$ & 2.78 & $27.3 \%$ & 42 \\
\cline { 2 - 5 } & $\geq 4$ & 3.17 & $7.8 \%$ & 12 \\
\hline \hline \multirow{2}{*}{$\geq 4$} & Difference: & 0.39 & $\mathrm{p}$-value $=0.256$ & - \\
\cline { 2 - 5 } & $\geq 4$ & 2.97 & $30.5 \%$ & 47 \\
\hline \multicolumn{2}{|r|}{ Difference (both $\geq 4$ - both $<4$ ): } & 3.62 & $34.4 \%$ & - \\
\hline \hline \multicolumn{2}{|c|}{} & $\mathbf{0 . 8 4 * * *}$ & $\boldsymbol{p}$-value $<\mathbf{0 . 0 0 1}$ & - \\
\hline
\end{tabular}

In Table 14 all differences in competitiveness are very large. It must be underlined that for companies in this group, firms that do not set goals are always less competitive than their closest competitors, regardless of whether they value knowledge or not. There is a large group of companies - almost one third of the sample $(30.5 \%)$ - that place high value on knowledge but do not set goals and, in effect, are less competitive than their closest competitors (Competitiveness Index $=2.97$ ).

Only $34.4 \%$ of high and medium-high technology firms have a positive attitude to knowledge and goal setting; all these enterprises are very competitive - Competitiveness Index: 3.62. It can be concluded that for high and medium-high technology manufacturing firms positive attitudes in both key areas - the appreciation of the importance of knowledge and goal setting - are especially important.

The results of the logistic regression model for high and medium-high technology manufacturing companies are presented in Table 15.

Table 15. Testing Global Null Hypothesis

\begin{tabular}{|l|c|c|c|}
\hline \multicolumn{4}{|c|}{ Testing Global Null Hypothesis: BETA=0 } \\
\hline Test & Chi-Square & DF & $\operatorname{Pr}>$ ChiSq \\
\hline Likelihood Ratio & 22.6548 & 2 & $<\mathbf{0 . 0 0 0 1}$ \\
\hline Score & 22.1994 & 2 & $<\mathbf{0 . 0 0 0 1}$ \\
\hline Wald & 20.7858 & 2 & $<\mathbf{0 . 0 0 0 1}$ \\
\hline
\end{tabular}

Source: results produced using SAS software

According to Table 15, the null hypothesis should be rejected. The model is valid for high and high-tech manufacturing firms. The analysis continues with the presentation of maximum likelihood estimates in Table 16.

Table 16. Analysis of Maximum Likelihood Estimates

\begin{tabular}{|r|c|c|c|c|c|}
\hline \multicolumn{7}{|c|}{ Analysis of Maximum Likelihood Estimates } \\
\hline Parameter & DF & Estimate & $\begin{array}{c}\text { Standard } \\
\text { Error }\end{array}$ & $\begin{array}{c}\text { Wald } \\
\text { Chi-Square }\end{array}$ & Pr $>$ ChiSq \\
\hline Intercept & 1 & -3.1222 & 0.7606 & 16.8493 & $<0.0001$ \\
\hline Goal setting & 1 & 1.4939 & 0.3655 & 16.7107 & $<0.0001$ \\
\hline Importance of knowledge & 1 & 0.3703 & 0.3915 & 0.8946 & 0.3442 \\
\hline
\end{tabular}

Source: results produced using SAS software

For high and medium-high technology manufacturing enterprises one of the independent variables - Importance of knowledge - is not statistically significant for $\alpha=0.05$. However, the other one - goal setting is significant. Table 17 presents odds ratio estimates. 
Table 17. Odds Ratio Estimates

\begin{tabular}{|r|c|c|c|}
\hline \multicolumn{4}{|c|}{ Odds Ratio Estimates } \\
\hline Effect & $\begin{array}{c}\text { Point } \\
\text { Estimate }\end{array}$ & \multicolumn{2}{|c|}{$\begin{array}{c}\text { 95\% Wald } \\
\text { Confidence Limits }\end{array}$} \\
\hline Goal setting & 4.455 & 2.176 & 9.118 \\
\hline Importance of knowledge & 1.448 & 0.672 & 3.119 \\
\hline
\end{tabular}

Source: results produced using SAS software

For high and medium-high manufacturing companies that set goals, in comparison to those that do not, the probability of being more competitive than their closest competitors is almost 4.5 times higher. For enterprises that perceive knowledge as an important factor, in comparison those that do not, the probability of being more competitive than their closest competitors is almost 1.45 times higher. However, the last variable is not statistically significant. R-Square and max-rescaled R-Square values are shown in Table 18.

Table 18. R-Square and Max-rescaled R-Square values

\begin{tabular}{|r|r|r|r|}
\hline$R$-Square & 0.1368 & Max-rescaled $R$-Square & 0.1842 \\
\hline
\end{tabular}

The R-Square value for the model in the case of high and medium-high technology manufacturing companies is 0.1368. This is a medium-low result but one that is higher than the corresponding value for all manufacturing companies combined and for low and medium-low technology companies. It represent a low goodness-of-fit of the model. The following figure shows the ROC Curve for the model.

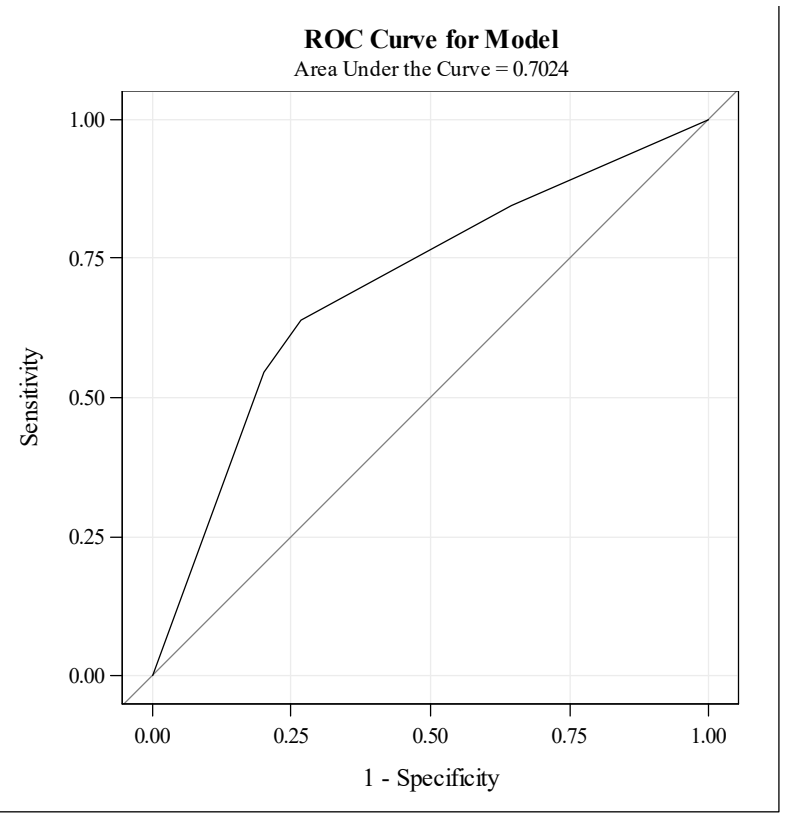

Figure 3. ROC Curve for the model - high and medium-high technology manufacturing companies Source: results produced using SAS software

The area under the ROC Curve for high and medium-high manufacturing companies is the largest of the groups of firms analysed in the article. It is significantly greater than 0.5 and exceeds 0.7 . 


\section{Issues in Information Systems \\ Volume 18, Issue 2, pp. 20-30, 2017}

\section{SUMMARY}

The results presented in the article show that the majority of manufacturing companies view knowledge as an important resource. The remaining part (41.62\%) attach less importance to this area and are less competitive than their closest competitors. The difference in competitiveness between these two groups is considerable -0.50 . With respect to goal setting, the results show an opposite pattern: the majority of manufacturing firms do not consider this area to be equally important. However, the difference in competitiveness between these two groups is also considerable -0.53 .

Distinguishing between two types of manufacturing companies using the OECD criterion of the technological level of manufactured products provides a new perspective on the research question. The results show that valuing knowledge is more important for competitiveness of low and medium-low technology manufacturing companies. On the other hand, goal setting is especially important for medium-high and high technology manufacturing companies.

One may expect that it is obvious for managers of medium-high and high technology companies that knowledge is crucial for their companies. It turns out that for low and medium-low technology companies it is not as obvious as might be expected, but the results suggest that under current economic conditions knowledge is exactly what these enterprises should concentrate on if they want to be competitive.

Despite interesting insights obtained from analysing the importance of knowledge and goal setting separately, the most important findings come from the analysis of synergy effects. In the entire sample of manufacturing companies the difference in competitiveness between companies that value knowledge and goal setting in comparison to those that do not was 0.74 and was statistically significant.

The most interesting fact is that for all manufacturing companies combined a positive attitude to goal setting did not have a significant effect on competitiveness if they did not value knowledge. Moreover, the maximum mean value of the Competitiveness Index for this group was 3.00, which denotes "more less the same as closest competitors". This means that attention paid to goal setting without a positive attitude to knowledge does not contribute to a higher competitive advantage for manufacturing companies.

Manufacturing companies that value knowledge but do not pay attention to goal setting were slightly more competitive (Competitiveness Index=3.05) than those that do the opposite (Competitiveness Index=3.00). However, companies that have a positive attitude to knowledge and goal setting were significantly more competitive (Competitiveness Index=3.54).

The results show that there is a synergy effect between goal setting and the positive attitude to knowledge among manufacturing companies. The synergy effect is also visible for low and medium-low technology manufacturing companies but is weaker than in the entire sample of manufacturing companies. The strongest synergy effect could be observed for high and medium-high technology manufacturing enterprises. The difference in competitiveness between companies that have a positive attitude in both areas and those that do not is 0.84 - the highest value reported in this article. For these companies a positive attitude in both areas is especially significant for their competitiveness. The absence of one element inhibits the competitiveness of such companies, an outcome which is particularly evident in the case of ignoring the importance of goal setting

\section{MANAGERIAL IMPLICATIONS}

There are several useful, practical implications that can be extracted from this study. First of all, for any manufacturing company, it is better to concentrate on both key areas - knowledge and goal setting. This attitude contributes to increasing the competitiveness of the surveyed enterprises. Nevertheless, there were visible differences key areas between the two groups of manufacturing companies: low and medium-low technology vs. high and medium-high technology.

Low and medium-low technology manufacturing companies should concentrate more on developing knowledge. Currently, they are lagging behind medium-high and high technology manufacturing companies in this respect, and more attention paid to this aspect may improve their competitiveness. As for goal setting, it is especially important for competitiveness of high and medium-high technology manufacturing firms.

The final, most important general conclusion is that for manufacturing companies there is usually no point focusing on knowledge development if they do not set goals, because it does not contribute much to their competitiveness. 


\section{Issues in Information Systems}

Volume 18, Issue 2, pp. 20-30, 2017

Empirical research results indicate that this is an especially important suggestion for medium-high and high technology manufacturing companies.

\section{REFERENCES}

Drozdowicz-Bieć, M. (2014). PKB wzrasta, ale gospodarka nie nowocześnieje [GDP is rising, but the economy is not becoming more modern], obserwatorfinansowy.pl, available: https://www.obserwatorfinansowy.pl/tematyka/makroekonomia/pkb-wzrasta-ale-gospodarka-nienowoczesnieje/ (23.04.2017).

Fonfara, K. (2007). Typologia zachowań przedsiębiorstw w procesie internacjonalizacji [Typology of enterprises' behaviour in the process of internationalisation]. Marketing i Rynek, 12, 10-15.

Gaczek, W.M. (2009). Gospodarka oparta na wiedzy w regionach europejskich [Knowledge-based economy in European regions], Warszawa: Komitet Przestrzennego Zagospodarowania Kraju PAN.

Hatzichronoglou, T. (1997). Revision of the High Technology Sector and Product Classification. OECD Science, Technology and Industry Working Papers, 1997/02, OECD Publishing, Available: http://dx.doi.org/10.1787/134337307632 (26.03.2012).

Healthcare Registration (2010). Effective Goal Setting. Applying SMART goals, Aspen Publishers Inc., September, 5-6.

Kaźmierczyk, J. (2011). Technologiczne i społeczno-ekonomiczne determinanty zatrudnienia w sektorze bankowym w Polsce [Technological and socio-economic determinants of employment in the Polish banking sector], Warszawa: CeDeWu.

Locke, E. A., \& Latham, G. P. (2002). Building a Practically Useful Theory of Goal Setting and Task Motivation. A 35-Year Odyssey. American Psychologist, 57(9), 705-717.

Neef, D., Siesfeld, G.A.,\& Cefola, J. (1998). The Economic Impact of Knowledge, Boston: ButterworthHeinemann.

Powell, W.W., \& Snellman, K. (2004). The Knowledge Economy. Annual Review of Sociology, 30.

Roth, W.F. (2015). Strategic Planning as an Organization Design Exercise. Performance Improvement, International Society for Performance Improvement, 54(6), July, 6-12.

Soniewicki, M. (2015). The company's international competitive advantage - the role of knowledge, Warsaw: Difin.

Soniewicki, M. (2016). Knowledge Acquisition and Competitiveness of Manufacturing Enterprises, International Journal of Business Development and Research, 1, 27-42.

Stansfield, T. C., \& Longenecker C. O. (2004). The effects of goal setting and feedback on manufacturing productivity: a field experiment. International Journal of Productivity and Performance Management, 55(3/4), 346-358.

White, E.M., \& Flores, B. (1987). Goal Setting in the Management of Operations. International Journal of Operations \& Production Management, 7(6), 5-16.

Woldt, J. (2015). Strategic goal setting. Credit Union Magazine, 81(10), 30-33.

Woodall, J., Lee, M., \& Stewart, J. (2004). The knowledge revolution and the knowledge economy: the challenge for HRD. New Frontiers in HRD, London: Routledge.

Xenikou, A., \& Simosi, M., (2006). Organizational culture and transformational leadership as predictors of business unit performance. Journal of Managerial Psychology, 21(6), 566-579. 